\title{
Slithering Down the Plank of Intellectualism? The Canadian Conference of Christian Educators and the Impulse towards Accreditation among Canadian Bible Schools during the 1960s
}

\author{
Bruce L. Guenther
}

The scholarly analysis of accreditation among Bible schools and colleges remains a significant historiographical lacuna. This article examines the emerging impulse towards accreditation within the Bible school movement in western Canada during the turbulent 1960s, a critical decade in the development of evangelical theological education in Canada. The central focus is the origin, activities, and influence of a conference known as the Canadian Conference of Christian Educators (CCCE), an annual gathering of evangelical educators that began meeting in 1960. The prominent presence of personnel from the newly formed Accrediting Association of Bible Colleges (AABC), who were keenly interested in extending their organization into a region with the largest concentration of Bible schools in the world, raised expectations among Canadian evangelical educators about the possibility of a new level of respectability and recognition for their schools among public universities in Canada. Bible college educators in Canada soon discovered that AABC accreditation did not mean the same thing within the post-secondary educational landscape of Canada as it did in the United States. This resulted in an ambivalent relationship between AABC and the emerging Bible colleges in Canada, and prompted some Canadian leaders to investigate other avenues towards academic recognition. Illustrating the polarized response towards accreditation within the Bible school/college movement are two brief institutional studies of Mennonite Brethren Bible College in Winnipeg, Manitoba, and Prairie Bible Institute in Three Hills, Alberta. The differences reflect the variegated character of an evolving evangelicalism in western Canada. By the end of the 1960s, the significant American influence within the CCCE had been displaced by Canadian initiative and leadership, thus signalling the beginning of a new chapter in evangelical higher education in Canada.

L'analyse académique de l'accréditation parmi les écoles et collèges bibliques demeure une lacune historiographique significative. Cet article examine la poussée émergeante vers l'accréditation au sein du mouvement des écoles bibliques dans l'ouest du Canada durant les turbulentes années '60, une décennie critique dans le développement de l'éducation évangélique au Canada. Le principal point d'analyse est l'origine, les activités et l'influence d'un groupement connu sous le nom de "Canadian Conference of Christian Educators " (CCCE), une association d'éducateurs évangéliques qui ont débuté leur rencontres annuelles en 1960. La présence proéminente de personnel provenant de l' " Accrediting Association of Bible Colleges » (AABC) une association toute nouvellement formée et vivement intéressée à étendre leur organisation dans une région où se retrouvait la plus grande concentration d'écoles bibliques dans le 
monde, a fait naître des attentes parmi les éducateurs évangéliques canadiens au sujet de la possibilité d'un nouveau niveau de respectabilité et de reconnaissance pour leurs écoles parmi les universités du Canada. Les éducateurs des collèges bibliques du Canada ont rapidement découvert que l'accréditation de l'AABC pour le territoire canadien de l'éducationnel post-secondaire ne représentait pas la même chose au Canada que ce qui était fait aux Etats-Unis. Ceci a produit une relation ambivalente entre l'AABC et les collèges bibliques qui émergeaient au Canada, et a poussé quelques leaders canadiens à investiguer d'autres avenues pour l'accréditation académique. Une brève étude de deux institutions, le « Mennonite Brethren Bible College » au Manitoba, et le « Prairie Bible Institute » à Three Hills en Alberta, illustre la réponse polarisée à l'accréditation parmi le mouvement des écoles/collèges bibliques. Les différences reflètent le caractère varié d'un mouvement évangélique en évolution dans l'ouest du Canada. A la fin des années '60, l'influence américaine significative au sein du CCCE a été supplantée par l'initiative et le leadership canadiens, signalant ainsi le début d'un nouveau chapitre dans l'éducation évangélique au Canada.

Since launching the first Bible school in Canada in 1885, evangelical Protestants have initiated a myriad of approximately 240 such institutions throughout the country. ${ }^{1}$ By training church workers, pastors, and missionaries who have gone to every corner of Canada and the world, by organizing innumerable Bible and mission conferences, and by utilizing radio broadcasts and literature, these schools have influenced the lives of hundreds of thousands of people. Because of their contribution to the remarkable growth experienced by evangelical Protestantism in Canada, they were arguably among the most important Canadian evangelical institutions during the twentieth century. ${ }^{2}$

Like other religious institutions in North America, Bible schools have faced their share of challenges and change during the past century. Bible schools typically offered a Bible-centred, intensely practical, lay-oriented program of post-secondary theological training. As educational institutions, they operated in a zone between the upper years of secondary education and the undergraduate years of post-secondary education. They can be

1 I gratefully acknowledge the financial support of the Trinity Western University Small Grant program funded by the Social Sciences and Humanities Research Council of Canada. The insightful comments and suggestions by Robert Burkinshaw, Larry Perkins, Walter Unger, and the anonymous Historical Studies in Education reviewers have also been greatly appreciated.

2 For a more comprehensive analysis of the Bible school movement in western Canada, see Bruce L. Guenther, "Training for Service: The Bible School Movement in Western Canada, 1909-1960" (Ph.D. diss., McGill University, 2001). This study serves as a Canadian counterpart to Virginia Brereton, Training God's Army: The American Bible School, 1880-1940 (Indianapolis: Indiana University Press, 1990). 
differentiated from Bible colleges, which were accredited, conferred degrees, and possessed curricula including significantly more liberal arts or general education courses alongside course offerings in religious studies. More dynamic than most decades were the turbulent 1960s, a period that has been identified by scholars as a watershed time of transition for evangelical Protestants in Canada. ${ }^{3}$ Following an earlier pattern among their American neighbours during the 1940s, many Bible school leaders in Canada became increasingly interested in improving the academic status of their schools during the 1960s. ${ }^{4}$ This interest was closely related to the sweeping changes taking place simultaneously within the broader academic community in Canada as higher education became increasingly linked to the technological and economic growth of the country. ${ }^{5}$ Students with high school diplomas, along with their parents, began demanding more recognition in the form of degrees and transferable credit for the time and money spent at Bible schools. As some Bible schools moved closer to the post-secondary educational mainstream they gave up (or at least exchanged) their distinctive Bible school priorities for a related, but somewhat different, set of educational objectives. The impulse towards accreditation during the 1960s was the first step towards the "universitizing" of Bible schools that led a good number of Bible schools in Canada to become Bible colleges. ${ }^{6}$ Among Canadian Bible schools, the term "accreditation"

3 John G. Stackhouse, Jr., asserts that the decade of the 1960s was an important time of transition for evangelical Protestants in Canada, during which transdenominational institutions that had previously been differentiated by "sectish" and "churchish" mentalités began to discover and to trust one another, thereby creating a network of interlocking institutions comprised of a mutually supportive fellowship of organizations and individuals: Canadian Evangelicalism in the Twentieth Century: An Introduction to Its Character (Toronto: University of Toronto Press, 1993), 177-204.

$4 \quad$ By 1960 approximately half of the Bible schools in the United States identified themselves as colleges: see William C. Ringenberg, The Christian College: A History of Protestant Higher Education in America (Grand Rapids, MI: Eerdmans, 1984), 157-73. 5 Paul Axelrod, Scholars and Dollars: Politics, Economics and the Universities of Ontario, 1945-1980 (Toronto: University of Toronto Press, 1982), 36-37; and "Service or Captivity? Business-University Relations in the Twentieth Century," in Universities in Crisis: A Medieval Institution in the Twenty-first Century, ed. William A.W. Neilson and Chad Gaffield (Montreal: Institute for Research on Public Policy, 1986), 45-68.

$6 \quad$ Stackhouse, Canadian Evangelicalism in the Twentieth Century, 191-92, and Robert K. Burkinshaw, "Evangelical Bible Colleges in the Twentieth Century," in Aspects of the Canadian Evangelical Experience, ed. G.A. Rawlyk (Montreal and Kingston: McGillQueen's University Press, 1993), 373. Although not all Bible schools experienced an institutional "identity crisis" during the 1960s, eventually all Bible schools had to decide whether to pursue accreditation and become degree-granting "colleges," or whether their mandate (or resources) dictated remaining a Bible school. 
has been used in a general sense to describe the improvement of academic standards for the purpose of granting degrees and for obtaining recognition by other post-secondary institutions through one of several possible arrangements including membership in the Association for Biblical Higher Education (formerly known as the Accrediting Association of Bible Colleges, or simply as AABC), affiliation with a university, or a formal transfer credit agreement with other post-secondary colleges and universities. ${ }^{7}$ Within a decade, interest in accreditation significantly changed the complexion of the Bible school/college movement in Canada. ${ }^{8}$

Considerable scholarly attention has been given to analyzing the secularization of educational institutions in the United States that once considered themselves "Christian." ${ }^{9}$ Not only have these studies generated debate about the contemporary relationship between religion and the academy within North America, but they

7 I will use the acronym AABC throughout this article because that was how the organization was known during the 1960s. It was first called the Accrediting Association of Bible Institutes and Colleges; this was shortened in 1957 to the Accrediting Association of Bible Colleges. It was changed again in 1973 to the American Association of Bible Colleges. In 1994, the name was changed back to the Accrediting Association of Bible Colleges in order to indicate more accurately the territorial range of its services. The most recent name change took place in June 2004. It is operated by its member colleges through a board of directors, members of which are elected at annual meetings. For histories of this organization see Gordon G. Talbot, "A Study of the Accrediting Association of Bible Colleges from 1947 through 1966” (Ph.D. diss., New York University, 1968); and John Mostert, The AABC Story: Forty Years with the American Association of Bible Colleges (Fayetteville, AR: AABC, 1986).

8 For a more extensive discussion of various definitions of accreditation and their applicability within Canada see Peter S. Rae, "Unholy Alliance? The Church and Higher Education in Canada" (Ph.D. diss., University of Manitoba, 1998), 28-31.

9 See for example George A. Marsden, The Soul of the American University: From Protestant Establishment to Established Nonbelief (New York: Oxford University Press, 1994), and James Tunstead Burtchaell, The Dying of the Light: The Disengagement of Colleges and Universities from their Christian Churches (Grand Rapids: Eerdmans, 1998). Although a number of general surveys of theological education in Canada have been done (see for example D.C. Masters, Protestant Church Colleges in Canada: A History [Toronto: University of Toronto Press, 1966], the study of secularization in Canada has focused more on the changing role of organized religion within Canadian life than on changes in higher education. See Ramsay Cook, The Regenerators: Social Criticism in Late Victorian English Canada (Toronto: University of Toronto Press, 1985); Hans Mol, "The Secularization of Canada," Research in the Social Scientific Study of Religion 1 (1989): 197-215; Michael Gauvreau, The Evangelical Century: College and Creed in English Canada from the Great Revival to the Great Depression (Montreal and Kingston: McGill-Queen's Press, 1991); Gregory Baum, The Church in Quebec (Outremont: Novalis, 1991); David B. Marshall, Secularizing the Faith: Canadian Protestant Clergy and the Crisis of Belief, 1850-1940 (Toronto: University of Toronto Press, 1992); and John G. Stackhouse, "Who is to Say? Defining and Discerning Secularization in Canadian Christianity," Historical Papers: Canadian Society of Church History (1994): 193-200. 
have also been of particular interest to those anxious about preserving the distinctly religious identity and autonomy of private religious schools. While historiographical awareness of the Bible school/college movement has gradually increased during the past decade, a scholarly exploration of accreditation and its impact on Bible schools and colleges remains to be done in both Canada and the United States. ${ }^{10}$ This article examines the early interest in, and response towards, accreditation on the part of Bible schools and colleges during the tumultuous 1960s, a period of massive transformation of higher education in Canada. It focuses specifically on the activities and influence of the Canadian Conference of Christian Educators (CCCE), an annual gathering of Bible school leaders in western Canada that began meeting in 1960 and became, eight years later in 1968, the Association of Canadian Bible Colleges. The detailed historical records of the conference offer a unique window through which to observe the interaction between evangelical educators from the United States and Canada at a critical juncture in the development of evangelical theological education in Canada. ${ }^{11}$

Of particular significance was the role played by the American educator Safara A. Witmer, the first full-time executive director of the AABC, who was interested in using the CCCE to extend the recently-formed $A A B C$ into Canada. Witmer's initiative served as a catalyst in the formation and early operation of the CCCE, which then became a convenient platform from which to promote AABC to a Canadian audience. Witmer's role in initiating CCCE and his personal interest in Canada were not coincidental. His grandparents

10 This lacuna has been recognized (and lamented) more readily by historians of religion than education. The late George A. Rawlyk, for example, observed that "the transformation of many of the Bible colleges into accredited academic institutions is a fascinating development and one that certainly demands serious study": "Protestant Church Colleges in Canada: Past and Future," in The Secularization of the Academy, ed. George M. Marsden and Bradley J. Longfield (New York: Oxford University Press, 1992), 298. Although general studies of accreditation among Bible colleges do not exist, several people have focused on curricular developments: see Douglas T. Stave, "Curricular Change in Selected Bible Institutes and Colleges" (Ed.D. diss., University of Oregon, 1962), and Peter R. Gazard, "A Needs Assessment of Transfer Credit Procedures in Canadian Bible Colleges” (Ph.D. diss., University of Calgary, 1980).

11 Following each annual conference, the CCCE executive produced a mimeographed booklet containing copies of papers presented, meeting minutes, transcripts of presentations, and lists of participants. They were intended to provide, as one secretary put it, "an intelligible summary" of the event, and were distributed to stimulate interest on the part of other Bible schools/colleges. Copies of annual CCCE reports can occasionally be found in Bible school and college archives; a complete set is located in the Prairie Bible College Archives (hereafter PBCA), Three Hills, Alberta. 
were Mennonite immigrants who settled in the United States, but who maintained contact with relatives in Canada. Following his graduation from Fort Wayne Bible Training School in 1922, Witmer's first experience in professional ministry took place in the rugged terrain of western Canada, where he travelled mostly by horse. He returned eight years later for another short stint. His marriage in 1924 to Edith McLean, whom he met as a student at Fort Wayne, but who was born and raised in Ontario, strengthened still further his interest in Canada. ${ }^{12}$ Witmer promoted membership within AABC to Canadian evangelical educators as a path towards a new level of academic respectability and recognition for their schools among universities in Canada. Moreover, AABC personnel encouraged faculty members in Canadian Bible schools and colleges to enrol in graduate programs at certain evangelical schools in the United States. The presence of AABC personnel within the CCCE created a conduit of American influence into the developing world of evangelical theological education in Canada.

CCCE events became important occasions for Canadian educators to consider not only the possibilities and pitfalls of membership within AABC, but also a broader range of approaches to accreditation. At the outset Canadian educators relied heavily on the American experts from AABC in giving direction to the discussion surrounding accreditation. As it became clear that the contours of the educational landscape in Canada were very different than in the United States, the realization followed that the AABC approach towards accreditation would not easily achieve the same results in Canada as it had in the United States. Canadian leaders, therefore, began to assume more initiative in defining the agenda for conference meetings. Institutions that sent delegates to the CCCE varied considerably in their response to accreditation, which ranged from aggressive pursuit and whole-hearted endorsement to resistance and outright rejection. Illustrating these polar opposite responses towards accreditation are two revealing glimpses into the internal dynamics of Mennonite Brethren Bible College and Prairie Bible Institute. Personnel from both schools were actively involved in the CCCE despite their differences concerning accreditation. These variations were rooted in the disagreements among evangelical Protestants in Canada concerning the appropriate relationship between Christians and society, and

12 Timothy Warner, "Safara A. Witmer," in S.A. Witmer: Beloved Educator (Wheaton, IL: Accrediting Association of Bible Colleges, 1970), 7-21. 
thus offer insight into the variegated nature of evangelical Protestantism during the 1960s.

\section{An Introductory Snapshot of the Bible School Movement in Western Canada}

A brief sketch of the Bible school movement in western Canada offers a useful backdrop for the story of the CCCE. ${ }^{13}$ Despite being a sparsely populated area with memories of its pioneering heritage, a vastly disproportionate number of Canadian Bible schools were located in western Canada: less than 20 per cent of the country's population lived in the region, yet it contained more than 70 per cent of the Bible schools started in Canada prior to $1960 .{ }^{14}$ In fact, during the first half of the twentieth century the area contained the largest concentration of Bible schools anywhere in the world. More than one-third of the approximately 110 schools started in western Canada before 1960 were strategically situated within the region's emerging urban centres.

The Bible school movement in Canada has often been associated with several transdenominational schools that eventually became the larger schools - for example, Prairie Bible College, located in Three Hills, a small village 120 kilometres north-east of Calgary, Alberta, enrolled almost 900 students in the late 1940s, making it the largest Bible school in the world; and Briecrest College, now located in Caronport, Saskatchewan, which surpassed Prairie Bible College in enrolment during the mid-1980s. To be sure, the transdenominational schools were an important part of the overall configuration. What is not so well known is that the twelve transdenominational schools that began in western Canada prior to

13 Western Canada has been recognized as a unique region within Canada by political, social, and cultural historians. Examples of studies that are especially sensitive to the unique history and culture of western Canada include Robert Wardhaugh, Toward Defining the Prairies: Region, Culture and History (Winnipeg: University of Manitoba Press, 2001), and Robert K. Burkinshaw, Pilgrims in Lotus Land: Conservative Protestantism in British Columbia, 1917-1981 (Montreal and Kingston: McGill-Queens University Press, 1995).

14 The disproportionate number of schools in western Canada was noted by S.A. Witmer, who published the first history of the Bible school movement in North America, The Bible College Story: Education with Dimension (Manhasset, NY: Channel Press, 1962), 55. He vaguely attributes the large number of schools in western Canada to what he calls the "less conservative conditions of the Canadian west" (52). See also Ian S. Rennie, "The Western Prairie Revival in Canada: During the Depression and World War Two," paper presented at the Oxford Conference on Revival, Oxford, UK, 1978. 
1960 were vastly outnumbered by a plethora of over ninety-five smaller schools operated by more than thirty different denominations. The cumulative enrolment in these denominational schools was more than double that of the cumulative enrolment in transdenominational schools. ${ }^{15}$

Although each school has its unique story, the dozens of individual institutional histories nevertheless share some significant commonalities in the way they are connected to aspects of the historical development of western Canada. Many schools were linked to denominational constituencies that owe their origins in Canada to immigration and that were, at the outset, extensions of much larger, more established denominational bodies located in the United States. The Bible schools in western Canada played an integral role both in developing leaders for, and nurturing a sense of Canadian identity within, these small and often isolated denominations. Leaders within denominational Bible schools in western Canada struggled with the problems of economic hardship and geographic isolation, their minority status alongside their larger denominational counterparts in the United States, and the desire to find local strategies that would both nurture an interest in Christian faith and guide the process of cultural assimilation within subsequent generations. The Bible schools were often the first denominational institutions to promote the use of English as the primary language and, as a result, they played an important role in helping the young people from various immigrant communities adjust to life in western Canada. Furthermore, many of the denominational schools served as the crucible for the convergence of European and North American theological influences.

The decade of the 1960s was a significant watershed for Canadian evangelical Protestants in general and, as noted above, for the Bible school movement in particular. During the first decades of the twentieth century, western Canada was a dynamic region as the infrastructure for a modern society was gradually being built. Times were rapidly changing for western Canadians during the 1950s as technological advances in transportation and communication, which accompanied the post-World War Two economic boom, made the vastness of the prairies less formidable

15 Without minimizing the role denominational schools played within their own constituencies, it is fair to say that, on their own, few of these schools could be considered particularly significant in the overall development of the Bible school movement. But when placed together, they reveal that evangelical Protestantism in western Canada was significantly more denominational in its orientation than transdenominational during the first half of the twentieth century (Guenther, "Training for Service," 364). 
for its inhabitants. These factors, together with a vigorous demand for access to post-secondary education, plus other matters more specific to each school and its constituency, prompted denominations to consolidate their educational efforts to avoid an unnecessary duplication of services. The contribution of Bible schools to the development of a post-secondary educational infrastructure in western Canada has yet to be acknowledged by historians of higher education. For example, a comparison of enrolment statistics between the fledgling universities and the Bible schools in the region reveals that for every 3.5 university students enrolled in 1940, at least one person was enrolled in a Bible school. By 1950, this proportionate comparison had decreased to only five to one, indicating the significance of these schools in the overall educational landscape. ${ }^{16}$ Very few new schools were started during the decade leading up to 1960 - in fact, the number of schools that closed during the 1950s vastly outnumbered any new initiatives. Many smaller Bible schools were compelled either to close their doors or to merge with other schools. By 1960, only 40 per cent of the schools started in western Canada were still in operation. The schools remaining in operation were, therefore, particularly interested in considering changes that would enhance their ability to survive the second half of the twentieth century.

\section{Origins of the Canadian Conference of Christian Educators}

The first meeting of the CCCE was held on the campus of Canadian Bible College in Regina, Saskatchewan, in May 1960. Attended by approximately thirty delegates from fifteen schools located across the prairie provinces, the event marked the first formal gathering of Bible school/college leaders in Canada to discuss matters of common concern. Prior to this event, leaders from Bible schools scattered across Canada seldom had occasion for direct contact with one another, and often manifested little desire to meet with those who were generally considered as competitors. The inaugural CCCE conference left a favourable impression on the participants, and ended with a resolution to reconvene the following year and to extend an invitation to all other Bible schools and colleges across Canada to attend the next conference. ${ }^{17}$ Despite efforts to attract representatives from schools 
across Canada, the conference was dominated by schools located in western Canada. Initially responsible for organizing an annual conference, after eight years those involved in planning CCCE conferences decided to create an organization with a broader mandate. This led to the formation of the Association of Canadian Bible Colleges, which continues to operate today as an annual event for facilitating fellowship, networking, and professional development among faculty and staff at Canadian Bible schools and colleges.

The idea of an annual gathering for Bible school leaders emerged in 1958 when S.A. Witmer met informally at Canadian Bible College with eighteen representatives from six schools located in Alberta and Saskatchewan. ${ }^{18}$ The city of Regina was a convenient place to meet, both because it was centrally located on the prairies and because Canadian Bible College was preparing an application for membership with AABC. The presence at this meeting of Witmer, who was sometimes dubbed "Mr. Bible College" because of his aggressive promotion of Bible college education, and his role as a catalyst in inaugurating CCCE was a harbinger of AABC influence.

Immediately evident from the CCCE annual reports is the prominent (even overbearing) presence of $\mathrm{AABC}$ personnel during its first six years of operation. The CCCE executive committee, which was made up of individuals elected from the participating schools, solicited Witmer's involvement, as an invited guest, in giving direction and advice at virtually every stage in the planning of the first three conferences. In addition to his role as a consultant in the planning stages, he was repeatedly called upon as an expert on every aspect of Bible college life, delivering the majority of presentations during the first three conferences: three in 1960, four in 1961, and four in 1962. Following his death in 1963, other AABC personnel followed in Witmer's footsteps, most notably John Mostert, the second executive director of AABC, and Harold W. Boon (president of Nyack College and president of AABC). A regular item on each CCCE program until 1966 was an extended report of the AABC annual meetings usually held each October at Moody Bible Institute in Chicago. These detailed reports were intended to inform a Canadian audience of the activities of the

18 The schools represented at this inaugural planning meeting included Winnipeg Bible Institute and College, Canadian Bible College, Moose Jaw Bible College, Full Gospel Bible Institute, Mountain View Bible College, and Hillcrest Bible Institute (CCCE Report, 1960, 1). 
(See end of article) 
organization, and indicate the degree to which it was willing to welcome Canadian schools as part of its fraternity. The active involvement of AABC leaders helped shape the way Canadian Bible school leaders initially thought about accreditation.

\section{Historical Roots of the Accrediting Association of Bible Colleges}

The AABC began during the annual meeting of the National Association of Evangelicals (NAE) in October 1947. Officially organized in 1942, the NAE drew together a coalition of evangelical leaders from a network of relatively new evangelical denominations and transdenominational institutions that had given fundamentalism its strength during the late-nineteenth and earlytwentieth centuries. ${ }^{19}$ This new organization, together with the growing popularity of the Billy Graham Association and new educational institutions such as Fuller Theological Seminary, helped many fundamentalists emerge from their subculture and laid the foundation for a resurgence of evangelical Protestantism in America. ${ }^{20}$ Despite a new interest in engaging the broader culture, these "neo-evangelicals" maintained strong convictions about defending the authority of the Bible, the pre-eminence of evangelism, the necessity of a warm-hearted personal piety, and, for many, adherence to pre-millennial eschatology. NAE played an important role in encouraging a proliferation of affiliate organizations during the 1940s intended to extend the influence of the evangelical cause in America. ${ }^{21}$ Its slogan, "cooperation

19 See Joel A. Carpenter, "Fundamentalist Institutions and the Rise of Evangelical Protestantism, 1929-1942," Church History 49 (Mar. 1980): 62-75, and Joel A. Carpenter, Revive Us Again: The Reawakening of American Fundamentalism (New York: Oxford University Press, 1997), 147-60.

20 George M. Marsden, Reforming Fundamentalism: Fuller Seminary and the New Evangelicalism (Grand Rapids: Eerdmans, 1987), 3-10.

21 NAE either founded or inspired a variety of collaborative ventures including the Office of Public Affairs in 1943, the National Religious Broadcasters in 1944, the Evangelical Foreign Missions Association and World Relief in 1945, the National Sunday School Association and National Association of Christian Schools in 1947, the Evangelical Theological Society in 1949, and the Evangelical Press Association (see Carpenter, Revive Us Again, 150). The CCCE was not the only evangelical network emerging in Canada during the 1960s that reveals the influence of the NAE. Canadian involvement in NAE helped prompt a series of informal meetings during the early 1960s that led to the formation of the Evangelical Fellowship of Canada in 1964: see John G. Stackhouse, Jr., "The National Association of Evangelicals, the Evangelical Fellowship of Canada, and the Limits of Evangelical Cooperation," Christian Scholar's Review 25 
without compromise," signalled an attempt to avoid divisiveness among evangelicals and to be more "positive" in its involvement in society, and as a result, it was intentionally positioned between the more stridently separationist American Council of Christian Churches founded in 1941 by Carl McIntire, and the more liberal Federal Council of Churches. ${ }^{22}$

It was within this context that AABC was born. NAE leaders argued that the "only" solution for preserving the distinctive and indispensable elements of a Bible institute education was to organize their own accrediting agency committed to "sound collegiate standards" and "predicated on principles of Bible college education." 23 Within two years, AABC had accredited twelve schools. It was quickly recognized by the United States Office of Education as the official accrediting body in the field of undergraduate theological education. Accreditation with AABC gave Bible colleges in the United States equivalent status to state colleges, which enabled the transfer of credits to other postsecondary institutions. ${ }^{24}$ Schools accredited by AABC were recognized by the Department of Justice, Veterans Administration, and other federal agencies in the United States. By the time Witmer became involved in organizing the CCCE, thirty-seven schools (including two schools in Canada) had been granted full accreditation, and an additional ten had been given associate status.

AABC's roots within the NAE gave the organization a particular ethos. Like NAE, AABC intentionally sought to be a catalyst for co-operation among, and a convenor of, like-minded

(Dec. 1995): 161.

22 See James D. Murch, Cooperation Without Compromise: A History of the National Association of Evangelicals (Grand Rapids, MI: Eerdmans, 1956).

23 Howard W. Ferrin, cited in Witmer, The Bible College Story, 45-46. An earlier attempt to organize Bible school leaders from across North America for the purpose of improving and unifying standards was made in 1918 by James Gray, president of Moody Bible Institute. Thirteen years later in 1930 a more successful initiative was launched by Clarence $\mathrm{H}$. Benson, also from Moody, which became known as the Evangelical Teachers Training Association; see Jonathan N. Thigpen, "The Early Years of ETA-1930-1955," Journal of Adult Education (Fall 1999); Ringenberg, The Christian College, 168-69; and Witmer, The Bible College Story, 45. AABC was preceded also by a short-lived NAE affiliate called the North American Association of Bible Institutes and Bible Colleges, which was organized to "provide a vortex of fellowship" for Bible school and college leaders. Because of its lack of interest in accreditation, it readily gave way to formation of the new, and independent, AABC.

24 Accredited Bible Colleges: Why? (Fort Wayne, IN: Accrediting Association of Bible Colleges, n.d.); Ringenberg, The Christian College, 168-70; and McKinney, Equipping for Service, 174-78. 
evangelical educators. ${ }^{25}$ Not only was it genuinely interested, as an accrediting agency, in helping evangelical Protestant schools achieve a higher level of excellence and academic recognition, but it also supported the development of independent, and distinctly evangelical, educational institutions of higher learning. The recruitment of speakers from conservative evangelical colleges and seminaries in the United States included an implicit (and sometimes explicit) promotion of the institutions of which they were a part. Enticed by scholarships, many faculty members in Canadian Bible schools, interested in enhancing their academic credentials, enrolled in these American evangelical schools. ${ }^{26}$ This link to a network of conservative evangelical theological institutions south of the border connected Canadian evangelical educators to an expression of American evangelicalism that was intentionally distancing itself from fundamentalism. Moreover, it meant that faculty members from Canadian Bible schools and colleges seldom had opportunity to establish personal relationships with professors and leaders within Canadian seminaries and universities, thereby reinforcing the isolation of the private evangelical schools within the Canadian educational landscape. The connections to American schools shaped Canadian evangelical theological education for decades.

In addition, the distribution of resources written by $A A B C$ personnel describing the Bible school/college movement shaped the historiographical understanding of the Bible school movement in Canada among evangelical educators and religious historians for decades. Witmer's book, The Bible College Story: Education with Dimension, became the most influential and widely used study of the Bible school/college movement. ${ }^{27}$ The rise of the movement is attributed to the increased secularization of private denominational colleges, the advance of liberal theology and methods of Bible

25 During a presentation entitled, "Problems and Responsibilities Facing Canadian Bible Institutes and Colleges in This Decade," John Mostert talked about "promoting good understanding and appropriate relations with other educational institutions," and the need for a "positive rather than defensive approach" (CCCE Report, 1965, 4).

26 For example, on numerous occasions staff from Fuller Summer Seminary (also known as Winona Lake School of Theology) announced the availability of special summer school scholarships for Canadians (see CCCE Report, 1961, 5-6; CCCE Report, 1962, 11; and CCCE Report, 1963, 10). It reported that 25 per cent of its students were Canadian.

27 It is intriguing to note that the historiographical characterization of the Bible school movement as an expression of fundamentalism has been perpetuated both by those trying to marginalise or discredit the movement, and by those within the movement who have been influenced by fundamentalism and have tried to fortify the perception of Bible schools as the final bastions of orthodoxy. 
study that created a distrust among evangelicals for denominational seminaries, and the impact of nineteenth-century evangelism and missions through the influence of people such as R.A. Torrey, David Livingstone, and Hudson Taylor. $^{28}$ The general characterization of the entire Bible school movement as a fundamentalist reaction against secularism and liberalism ignores the more variegated denominational contours of the movement. ${ }^{29}$

$A A B C$ personnel recognized the strategic potential of the CCCE for extending its influence and organization into Canada. Involvement with these schools was a part of the organization's objective of assisting the Bible school movement in North America in obtaining academic recognition and exercising influence within society. The keen desire to promote AABC as the premier vehicle for providing academic recognition and facilitating professional development for Bible college personnel in Canada prompted the organization to subsidize the activities of the CCCE during its first years of operation.

\section{The Canadian Conference of Christian Educators and Accreditation}

Although the organizers of the CCCE never expressed any desire to form an accrediting agency that might serve as a Canadian counterpart to the AABC, from the outset the subject of accreditation was very much a central part of the agenda. ${ }^{30}$ This is not surprising considering the prominent presence of AABC. The

28 Witmer unfortunately ignored a passing reference to the Bible school movement by Richard Niebuhr that foreshadowed some of the historiographical nuances that surface in the studies by Guenther, "Training for Service,” 27-34, and to a lesser extent in Brereton, Training God's Army, xviii-xix, 155-164. Niebuhr noted, "the growth of the Bible school movement in the twentieth century is not always to be regarded as a phenomenon of the opposition of 'conservatives' to 'liberals.' It is an indication of the increased participation of certain groups in the United States and Canada in the general movement toward education. The conservative schools seem to have their origin less in antagonism to the 'liberal' schools than in the desire of conservative groups to provide higher education of a Christian type for their young people and particularly for their ministers": The Advancement of Theological Education (New York: Harper, 1957), 5.

29 Witmer, The Bible College Story; H.W. Boon, "The Development of the Bible College and Institute in the United States and Canada Since 1880 and its Relationship to the Field of Theological Education" (Ph.D. diss., New York University, 1950); and John Mostert, "Bible College Movement: Past, Present and Future," CCCE Report, 1964, 5-20. 30 The suggestion that a Canadian counterpart to AABC be formed was occasionally put forward, but never received wide support; see for example Gazard, "A Needs Assessment of Transfer Credit Procedures in Canadian Bible Colleges," 237. 
very first keynote address at the inaugural CCCE conference was an unabashed attempt by Witmer to convince leaders in Canadian Bible schools of the benefits of accreditation in general, and the merits of AABC as a "service agency" in particular. After clarifying that AABC was not designed to confer "social status," or to force schools to conform to a particular mould, Witmer outlined a list of benefits, including help in focusing attention on objectives; incentive to avoid "stagnation"; qualitative measurement of excellence; and professional guidance in conducting institutional self-evaluations. ${ }^{31}$ Aside from the question of whether Witmer's list in fact constituted "benefits," or whether AABC was capable of delivering them, the prominence of the subject does signal an interest on the part of Canadian evangelical educators in exploring new educational options for their schools.

Witmer's presentation was followed by an extensively researched survey by F.C. Peters concerning the "problems connected with Canadian accreditation and the difficulties faced by Canadian schools in their efforts to receive status in the community of Canadian institutions of higher learning."32 From his vantage point as a faculty member and academic dean at the Mennonite Brethren Bible College (MBBC) in Winnipeg, a school that had been accredited by AABC since 1950 and that was actively seeking an affiliation arrangement with several Canadian universities, Peters pointed towards various changes taking place within postsecondary education in Canada: for example, enrolments dramatically increased after the end of World War Two, and he surmised (correctly) that this enthusiasm for higher education would continue. ${ }^{33}$ In addition, significant increases in federal aid for Canadian universities and colleges had been announced. The

31 "The Accrediting Association of Bible Colleges, A Service Agency," CCCE Report, 1960, 5-6. For a fuller explanation see S.A. Witmer, "The Accrediting Association of Bible Colleges Looks Forward: A Manifesto," Address given at the Eleventh Annual Convention of the AABC (Fort Wayne, IN: AABC, 1960), 1-14.

32 CCCE Report, 1960, Appendix II.

33 Peters' presentation was based upon research done by the Educational Committee of the Canadian Mennonite Brethren Conference as it studied the liberal arts needs of students within the denomination; see 1960 Yearbook of the Fiftieth Canadian Conference of the Mennonite Brethren Church of North America (1960), 164-72. He brought a wealth of educational experience from both sides of the border, including attendance at several Mennonite Brethren Bible schools in Canada; academic degrees from Tabor College (a Mennonite Brethren liberal arts college in Hillsboro, Kansas), Waterloo Lutheran Seminary, and the University of Toronto; and administrative experience as president of Tabor College. See David Ewert, Honour Such People (Winnipeg: Centre for Mennonite Brethren Studies, 1997), 125-40. In addition, he completed doctoral degrees from Central Baptist Theological Seminary and the University of Kansas during his time at MBBC. 
trends identified by Peters were later substantiated by Statistics Canada: by 1960, enrolment in undergraduate university programs in Canada had increased by 73 per cent from fifteen years earlier. By 1965, only five years later, the total undergraduate enrolment numbers in Canadian universities increased by another 74 per cent, and by 1975, another decade later, by yet another 77 per cent. $^{34}$ Moreover, funding for public universities also increased exponentially during the 1960s. Per-student capita grants increased from five cents in 1957 to \$5.00 in 1965-66. The total federal aid to Canadian universities and colleges increased from $\$ 40$ million to $\$ 1$ billion, which resulted in a massive expansion of facilities and faculty.

After describing the pattern of higher education in Canada, which centred the delivery of liberal arts within the public universities, Peters explained the policy response on the part of the University of Manitoba to an inquiry concerning affiliation from a local Bible college. This was followed by a description of the junior college strategy used by the government of Alberta to distribute more broadly the delivery of liberal arts education, and the recent (and still somewhat tentative) transfer credit arrangement between MBBC and Waterloo Lutheran College (now Wilfrid Laurier University). He unambiguously endorsed the general pursuit of accreditation, arguing that "it is important to keep in touch with current educational trends" and to relate "the school to the [broader] academic community." ${ }^{35}$ Peters' presentation encapsulated the ideas of a small, but growing, minority of evangelical educators in Canada in 1960 who considered accreditation part of a necessary response to the broader changes taking place within the larger post-secondary academic community in Canada. ${ }^{36}$ His association with the first school to be accredited

34 Historical Compendium of Education Statistics from Confederation to 1975 (Ottawa: Statistics Canada, Education, Culture and Tourism Division, Projections and Analysis Section, 1984), 214-17.

35 Both Witmer and Peters considered it necessary to respond to the ongoing ambivalence (even suspicion) concerning accreditation that was evidently a sensitive matter among some within their audience. Both offered disclaimers: Witmer began his presentation by emphasizing that theological drift does not inevitably accompany accreditation. Peters concluded his by affirming that ultimately it is more important to be "accredited" by God than by "the world" (CCCE Report, 1960, 5, Appendix II).

36 The approach was echoed by Alvin Martin, president of Canadian Bible College, which made an unsuccessful attempt to obtain affiliation with the University of Saskatchewan during the mid-1950s, and which received full accreditation with AABC in 1961; see Ruth Mildred Martin, "The Canadian Bible College - History from 1941-1962" (M.A. thesis, Winona Lake School of Theology, 1962), 38-44. Martin argued that "the changing economic and cultural scene call for a better-trained ministry." He saw 
by AABC in Canada, and his personal involvement in discussing affiliation and accreditation possibilities with university administrators across the United States and Canada, gave him an understanding of, and first-hand experience with, both AABC and the world of higher education in North America that few, if any, other CCCE participants shared.

Glowing reports of the success of $\mathrm{AABC}$ in obtaining academic recognition for Bible colleges in the United States raised expectations among Canadian evangelical educators about the possibility of a new level of respectability and recognition for their schools among public universities in Canada. The presentation by Peters, however, drew attention to the differences between the development of higher education in the United States and Canada and the possible implications for the Bible schools and colleges. In Canada, education was a matter of provincial jurisdiction, and the federal government was not involved in organizing accrediting bodies for post-secondary education. ${ }^{37}$ Moreover, the desire to put an end to denominational conflict in the area of higher education, and the need for public funding on the part of church-colleges in order to remain financially solvent, prompted a transition in Canada towards publicly funded and secular (i.e., free from denominational control) universities. Validating this transition was the gradual evolution of the "idea" of provincial universities in Canada as necessarily public, autonomous, and secular entities, too important to be left in the hands of private, and divisive, "sectarian" interests. Although tolerance within Canada for church-state interplay continued to permit a pattern of affiliation between church colleges and public universities, an arrangement that few American evangelical educators could imagine because of the stricter separation of church and state interests in the United States, the suspicion of private church-related educational institutions was

\footnotetext{
a more academically rigorous and degree-granting Bible college program as the appropriate response to these changes: see "The Distinctive Features of Higher Education in Canada and the Goals of Canadian Bible College in Light of Them," unpublished report, c. 1968, 4-5. Similarly, denominational leaders pressured Hillcrest Christian College, located in Medicine Hat, Alberta, to integrate more liberal arts courses and to offer degree-granting programs for their church leaders: Theodore E. Jesske, Pioneers of Faith: A History of the Evangelical Church in Canada (Three Hills, AB: EMF Press, 1985), 293.

37 In the absence of any accrediting bodies, membership in the Association of Universities and Colleges in Canada became de facto a form of post-secondary accreditation in Canada: see Rae, "Unholy Alliance?" 29. The first post-secondary accrediting agency in Canada, the Private Colleges Accreditation Board of Alberta, was established in 1984 by the Government of Alberta.
} 
heightened in Canada by the assumption that only public, secular universities are able to offer education that is truly in the public interest. $^{38}$ The impact of these changes has been felt most strongly within western Canada, where the more recently formed provinces had the opportunity to begin with the "one-university" model entirely free of any denominational association. These changes created a post-secondary educational landscape where churchrelated institutions were (and sometimes still are) seen as anomalies, quite unlike the United States where private colleges have flourished. Significant for the purpose of this article is the way Bible college educators in Canada soon discovered that AABC accreditation did not mean the same thing within the postsecondary educational landscape of Canada as it did in the United States. ${ }^{39}$ This resulted in an ambivalent relationship between AABC and the emerging Bible colleges in Canada, and prompted some Canadian leaders to pursue other avenues towards academic recognition.

The presentations by Witmer and Peters laid the foundation for all subsequent discussions at CCCE events about accreditation. During the second conference in 1961, Witmer made more of an attempt to address the Canadian context than he had done the previous year. His address, entitled "AABC, A Service Agency for Canadian Institutions," first detailed the activities of the organization and then announced AABC's intention to "sharpen the image of AABC as a bi-national agency" and "to acquaint Canadian educators and organizations with the services and standards of AABC." The focus centred around the specific services AABC might offer Canadian schools, but like the year before, Witmer failed to address the crucial question of how accreditation with

38 Glen A. Jones, “The Idea of a Canadian University,” Interchange 29, 1 (1998): 76-77. Peter Rae suggests that Canadians place a higher value on order relative to freedom than do Americans, which has led Canada "to reject the hierarchical structures created by private systems and to opt for the broader egalitarianism of a more homogenous public system": "Unholy Alliance?" 14; see also 4-43, 69-74.

39 Despite receiving provincial charters for granting degrees, these deeper cultural values have effectively marginalised evangelical Bible colleges interested in obtaining academic recognition comparable to that accorded public universities. The difficulties (and in some cases overt prejudice) that private evangelical colleges have endured in Canada in their attempt to obtain academic recognition remains an unexplored (and often unacknowledged) subject. See Michael Skolnik, "Lipset's Continental Divide and the Ideological Basis for Differences in Higher Education between Canada and the United States," Canadian Journal of Higher Education 20, 2 (1990): 88-89, and John G. Stackhouse, Jr., "Respectfully Submitted for American Consideration: Canadian Options in Christian Higher Education," Faculty Dialogue 17 (Spring 1992): 70. 
AABC might help Bible colleges obtain recognition from other post-secondary institutions in Canada. His advice to Canadian schools on the matter was simply "to determine their own standards." Following Witmer's death, it became John Mostert's responsibility to profile and promote AABC through the CCCE. Each year, for the next three years, Mostert attended the annual CCCE events, and in addition to reporting on the annual meeting of the AABC, he was given a major slot on the program to do a presentation on some facet of the Bible college movement or AABC.

\section{"Proud of it": Accreditation and the Mennonite Brethren Bible College}

The choice of F.C. Peters as a presenter at the first CCCE was not accidental: the school with which he was associated led the move towards accreditation on the part of Bible colleges in Canada. Moreover, he was part of a denomination (Mennonite Brethren) that was deeply committed to religious education, and whose educational initiatives had frequently been imitated by others. Evidence of the denomination's interest in higher education was signalled as early as 1908 when a number of Mennonite Brethren individuals started a small liberal arts school, Tabor College, in Hillsboro, Kansas. After establishing several congregations in western Canada during the late-nineteenth century, Mennonite Brethren numbers in western Canada were boosted considerably by an influx of immigrants from Russia during the 1920s. Despite their relatively small membership in Canada - less than 14,000 in 1960 - the Mennonite Brethren were among the first to start Bible schools on the Canadian prairies, beginning with Herbert Bible School in 1913. By mid-century, they had established more than twenty Bible schools in Canada, more than any other denomination in the country, and their cumulative student enrolment significantly outnumbered that of any other denomination. These Bible schools were an educational genre adapted by Mennonite immigrants for the Canadian prairies as part of a multi-faceted strategy for ethnic and religious self-preservation. ${ }^{40}$

\footnotetext{
40 Bruce L. Guenther, “'Wrenching Our Youth Away from Frivolous Pursuits': Mennonite Brethren Involvement in Bible Schools in Western Canada, 1913-1960," Crux 38, 4 (Dec. 2002): 32-41.
} 
As early as 1939, denominational leaders began noting a shortage of well-qualified bilingual teachers for their numerous Bible schools. ${ }^{41}$ The sense of urgency for Bible school teachers was heightened further by the observation that too many prospective teachers were attending the "wrong colleges," that is, fundamentalist transdenominational schools, which were producing "unsuitable" instructors. This helped Mennonite Brethren leaders promote a vision for a school of higher learning that might reinforce the allegiance of young people to their own denomination. Others argued that the pastors of the future, particularly in the denomination's new urban churches, would require a more general education than that offered by the Bible schools to keep pace with lay people in their congregations. Still others expressed frustration when they saw their best ministerial candidates attend American colleges and not return to Canada. In response, a "higher Bible school" was established in 1944 in the metropolitan centre of Winnipeg with the declared purpose of training Bible school teachers, missionaries, and church workers. Within three years the new college became the largest Mennonite Brethren theological school in Canada, a status it continued to enjoy throughout the 1950s. By 1960, enrolment at MBBC equalled almost 50 per cent of the total enrolment in the remaining Mennonite Brethren Bible schools.

Shortly after starting the "higher Bible school," leaders were aware that the college could become significantly more than a curricular extension of the Bible schools. John B. Toews, who assumed the presidency after the first year of operation and was, like Peters, influenced by his experience at Tabor College, tried to position the school as a theological college with a limited number of liberal arts courses. This initiative was not, however, without its critics. $^{42}$ The desire to include liberal arts courses was aimed not

41 See Twenty-fifth Anniversary Publication of Mennonite Brethren Bible College, 1944-1969 (Winnipeg: Mennonite Brethren Bible College, 1969), 13-14, and "Schulbestrebungen in unseren Kreisen," in Verhandlungen der 30. Nördlichen DistriktKonferenz der Mennoniten-Brüdergemeinde, 1939, 24-27.

42 Many Canadian students had attended Tabor College, but during the 1940s the college came under suspicion by denominational leaders for harbouring "liberalism"; see Peter G. Klassen, "A History of Mennonite Education in Canada, 1786-1960" (D.Ed. diss., University of Toronto, 1970), 299; Paul Toews, Mennonites in American Society, 19301970: Modernity and the Persistence of Religious Community (Scottdale, PA: Herald Press, 1996), 79-82; and Abe J. Dueck, "Kanadier, Amerikaner and Russländer: Patterns of Fragmentation among North American Mennonite Brethren Churches," Journal of Mennonite Studies 19 (2001): 187-88. Toews therefore felt pressure from Canadian students who were no longer prepared to attend Tabor College, but wanted to take courses 
only at broadening the educational horizons of pastoral candidates, but also at positioning the college as a Christian alternative for Mennonite Brethren young people who had completed a high school diploma and were pursuing university education in unprecedented numbers. ${ }^{43}$

Early on, means were sought to validate the academic standards and status of the new college. From the outset transfer credit arrangements were made with its American counterpart, Tabor College. An internal resolution was adopted in 1945 to investigate the possibility of affiliation with the University of Manitoba in Winnipeg. ${ }^{44}$ When this initiative failed, the college turned towards the newly formed AABC, and was accepted into membership in 1950 almost a decade before any other school in Canada; it was, according to Peters, proud of its accredited status. ${ }^{45}$ This was made possible because MBBC, from the outset, intentionally sought to hire faculty members with academic degrees who could teach in both "Arts" as well as "Theology." Recognizing the limited pool of prospective faculty members within the denomination, leaders within MBBC were quick to encourage faculty members to further their education by assisting with tuition and by granting study sabbaticals. By the early 1960s, most faculty members held at least one graduate degree. ${ }^{46}$ This strategy also

that could be transferred to a university. Others within the denomination considered it unnecessary and inappropriate for a theological school to offer liberal arts courses. As a result, the place of liberal arts courses at a theological college remained an on-going debate within the denomination for decades: "Report of the Educational Committee," in Berichte und Beschluesse der fünfzigsten Kanadischen Konfernz der MennonitenBrüdergemeinde von Nord-Amerika abgehalten in Virgil, Ontario vom 2. bis 6. Juli, 1960, 165-68.

43 Denominational leaders emphasized that the new college was not intended as a replacement for the denominational Bible schools; it was rather an opportunity to make them better (see George G. Konrad, "Is There a Future for the Bible Institutes?" c. 1960). As an alternative to the public universities for Mennonite Brethren young people, the college was not so successful. By 1965 the number of Mennonite Brethren young people attending universities was almost double that of the enrolment in Mennonite Brethren Bible schools and more than three times the enrolment of Mennonite Brethren Bible College: John Wall, "The Church and Its Students," MB Herald, 7 Oct. 1966, 6.

44 Centre for Mennonite Brethren Studies Archive, Box 1, Folder Z, Papers and Essays, Alvin Klippenstein, "The Mennonite Brethren Bible College and College of Arts: A Critical Analysis of its History and Development with a Comparison of the Religious and Cultural with Respect to Social Change," unpublished paper, 1977, 7.

45 CCCE Report, 1960, 16.

46 John G. Doerksen, "Mennonite Brethren Bible College and College of Arts: Its History, Philosophy and Development" (Ph.D. diss., University of North Dakota, 1968), 88-89, 138-40. The academic degrees earned by faculty came from a variety of seminaries and universities. This brought a diversity to the school that was uncommon in most other evangelical Protestant schools at the time. 
made it feasible to pursue affiliation agreements with public universities, and MBBC successfully signed its first university affiliation agreement in 1961 with Waterloo Lutheran College. Another affiliation agreement was negotiated with the nearby University of Winnipeg in 1972, at which time the school decided to drop its AABC accreditation, becoming the first Bible college in Canada to do so. ${ }^{47}$

Although MBBC was initially started as part of a strategy for supporting a network of denominational Bible schools by training a new generation of leaders, the school quickly came to represent a new approach towards theological education on the part of a new generation of evangelical Protestants in western Canada. Although the denomination identified with many of the emphases and priorities of the fundamentalist movement that emerged during the first half of the twentieth century, Mennonite Brethren leaders during the 1960s did not share the same suspicion of higher education and desire for isolation. A significant impetus for the emergence of, in the words of John Stackhouse, a more "churchish" mentalité within Protestant evangelicalism in Canada came not only from transdenominational institutions and organizations, but also from denominational traditions that had, from the 1940s onward, a different, broader vision for educating their young people within a rapidly modernizing Canada. ${ }^{48}$

\section{“Completely Independent”: Accreditation and Prairie Bible Institute}

While a handful of schools in Canada aggressively pursued full membership with AABC during the 1960s, polar opposites to those who enthusiastically endorsed accreditation were Bible school

47 By the mid-1960s indications of MBBC's ambivalence towards AABC begin to appear. J.H. Quiring, president of MBBC, wrote: "It is evident that the Accrediting Association of Bible Colleges cannot have the same significance for the Canadian colleges as for their American counterparts... the association has been most helpful to us especially during the early years. It helped to set our sights and to raise our standards...[however] this affiliation has lost some of its significance. The benefit derived is chiefly by way of fellowship with other schools...” See AABC Archives, Letter from J.H. Quiring to John Mostert, 15 December 1965.

48 It is not coincidental that the schools in western Canada most interested in accreditation during the 1960s were located in urban centres. These schools had access to a wider range of options as they responded to changes within post-secondary education (for example, some schools tried to attract students from their constituency by offering residential facilities and the option of taking classes at both their institution and a local university even though no affiliation agreement existed). 
leaders who remained wary and expressed their fear that accreditation might be a Trojan horse by which "modernism" would invade the camp. Because of its size and international reputation, one of the more prominent and influential examples of opposition to accreditation was Prairie Bible Institute (PBI). While not all transdenominational schools were as resistant to accreditation as PBI (most notably Winnipeg Bible Institute and College of Theology), comparing the examples of MBBC and PBI highlights a pattern in which denominational schools in Canada generally tended to respond more quickly and more enthusiastically towards accreditation during the 1960s than did transdenominational schools.

The central personality at PBI was its long-time principal, L.E. Maxwell, who together with Fergus Kirk started the school in 1922 in southern Alberta. No single individual exercised more influence on the development of the school's identity than Maxwell. Although the school shared in common with other Bible schools an emphasis on teaching the Bible, practical training, pre-millennialism, personal holiness, and missions, the peculiar flavour attributable to the school was entirely due to the formative influence of Maxwell. The school became an embodiment of his unique holiness-fundamentalist theological emphases and priorities. One of the defining features of PBI was the pre-eminent place given to the training of individuals for missionary service. Maxwell believed "it is our supreme task...to prepare trained, schooled, disciplined, and fit young people, to 'make up the hedge, and stand in the gap' on the far-flung missionary fronts." 49

Another defining feature of PBI, which reflected its strong ties with American fundamentalism, was its intentional separation, rooted in a deep suspicion of relationships with organizations that might, even inadvertently, compromise the school's emphases. This suspicion was reinforced by the historiographical understanding of the Bible school movement as a bulwark raised up by God as an alternative to educational institutions that had succumbed to the

\footnotetext{
49 Cited in Philip W. Keller, Expendable! With God on the Prairies: The Ministry of Prairie Bible Institute, Three Hills, Alberta, Canada (Three Hills: Prairie Press, 1966), 38. For more on Maxwell and PBI see Donald A. Goertz, "The Development of a Bible Belt: The Socio-Religious Interaction in Alberta between 1925 and 1938" (M.C.S. thesis, Regent College, 1980), 87-99; and James Enns, "Every Christian a Missionary: Fundamentalist Education at Prairie Bible Institute, 1922-1947” (M.A. thesis, University of Calgary, 2000).
} 
forces of modernism. ${ }^{50}$ The single-minded devotion to its sense of mission even if it meant remaining independent and isolated determined the school's approach to accreditation. An early catalogue explained: "We believe that the continual temptation facing us as a Bible school is that of endlessly multiplying various subordinate and isolated studies, valuable as they may be, to the crowding out of the great objective of securing a first hand grasp of the whole Bible." 51 "We are not personally concerned," wrote Maxwell, "about becoming uniform with others, or in becoming accredited. God has given us a special method of Bible study second to none, and we are content to do what God wants us to do without having to adjust to that which others feel led to do...We are convinced that many of the present trends will ultimately take these very Bible institutes into modernism." ${ }^{52}$ Maxwell was afraid that even the expectations of an evangelical association such as AABC might distract it from its primary objective.

Due to pressure from several teachers during the 1950s to consider accreditation of both the high school and Bible school, which culminated in the departure of at least one teacher in $1957,{ }^{53}$

50 Lending at least some legitimacy to this suspicion were the well-known battles within Baptist circles during the first half of the twentieth century over Brandon College, which became a non-denominational college of the University of Manitoba in 1938, and McMaster University, which was relinquished by the Baptists Convention of Ontario and Quebec in 1957; see Walter Ellis, "What the Times Demand: Brandon College and Baptist Higher Education in Western Canada," and George A. Rawlyk, "A.L. McCrimmon, H.P. Whiddon, T.T. Shields, Christian Higher Education and McMaster University," in Canadian Baptists and Christian Higher Education, ed. George A. Rawlyk (Montreal and Kingston: McGill-Queen's University Press, 1988), 31-87; Samantha Thompson, "Brandon College and the Fundamentalist-Modernist Controversy, 1919-1926" (M.A. thesis, University of Calgary, 1990); and G. Keith Churchill, "Educational Policy of the Baptist Union of Western Canada, 1873-1975," in Canadian Baptist History and Polity: The McMaster Conference, ed. Murray J.S. Ford (Hamilton: McMaster Univ. Divinity College, 1982).

51 PBCA, PBI Catalogue (1926-27), 10.

52 Cited in Ringenburg, The Christian College, 170; see also Stackhouse, Canadian Evangelicalism in the Twentieth Century, 77, 135-37. The same sentiment continued to be expressed by Maxwell's successor, Ted Rendall, in 1970: "we believe that we must remain firmly committed to the distinctives that God has given to us as a Bible school...Prairie will remain unaffiliated...we can best pursue and promote our distinctives by remaining completely independent”: "The Seventies-Decade of Survival?" The Prairie Overcomer 43 (Feb. 1970): 7-8.

53 David Enarson left PBI in 1957 in frustration over the institution's refusal to consider accreditation. Together with Robert N. Thompson, a Social Credit, and later Progressive Conservative, Member of Parliament, Enarson put forward the vision that resulted in the formation of Trinity Western College (later renamed Trinity Western University) in Langley, British Columbia. See Hanson, From Hardship to Harvest, 13335; and David Enarson, Thine Hand Upon Me: He Tells it Like it Was, Memoirs of David Enarson (n.p., n.d. [(c. 1996]). The version put forward by PBI cites "repeated acts of 
Maxwell came close to relenting in his strident resistance to accreditation. As part of a strategy for resolving some of his own questions about the matter, Maxwell invited Witmer to visit the campus and issue an evaluative report of his findings. Witmer readily agreed, for to receive the endorsement of such a prominent critic would have been a significant coup.

In addition to interacting with Witmer, Maxwell privately solicited advice from individuals whom he trusted. He candidly shared with G. Allen Fleece, president of Columbia Bible College, an AABC-accredited school located in Columbia, South Carolina, with which PBI had unusually close fraternal relations, that a minority of PBI faculty favoured accreditation, but that he continued to have two primary concerns. First, "...a number of our teachers, including myself, who know their subjects and who would not be at all benefited by a degree, might be embarrassed or find themselves unable to teach at Prairie." Most PBI faculty members were former graduates with ministry experience, but generally without academic degrees. Second, although Maxwell acknowledged that "it should be no more wrong per se to secure a college diploma than a high school diploma," he nevertheless remained afraid that a move towards accreditation might well be the first step down the road "to the inevitable departure which has overtaken all such institutions in the past." ${ }^{54}$ In his response, Fleece indicated that his school had "experienced no problems whatever so far" as a result of membership in AABC. However, he expressed some apprehension about the possibility of a change in the "the general attitude of the Association from what has been the prevailing attitude and spirit until now." ${ }^{55}$ Fleece's fears were apparently realized shortly thereafter. In 1966 his school withdrew from AABC, accusing the association of "a wrong emphasis on intellectualism.." ${ }^{\text {"6 }}$ Maxwell appears to have accepted uncritically this same evaluation of AABC for in the same year he wrote: "Certainly the plank of intellectualism is that over which

duplicity" as the cause for dismissal: PBCA, "Minutes from the Meeting of the Board of Directors," 25 June 1957.

54 PBCA, Letter from L.E. Maxwell to G. Allen Fleece, 25 Feb.1960.

55 PBCA, Letter from G. Allen Fleece to L.E. Maxwell, 7 Mar. 1960.

56 PBCA, Letter from Ray and Helen Shepherd to L.E. Maxwell, 5 July 1966. 
fundamental and evangelical men slither finally and almost imperceptably [sic] into the school of liberal thought." ${ }^{27}$

Following his visit during the early months of 1960, Witmer sent a lengthy report to PBI in which he outlined twelve recommendations for consideration by the Board of Directors. The report marked a defining moment in the history of PBI. For Maxwell, it raised the spectre of how an external critique might be used to dictate the internal agenda of the school. Although Witmer had judiciously avoided making a recommendation either for or against accreditation, and was careful to indicate that his suggestions were not an accreditation checklist, his comments about the need for improvement in the area of curriculum, library, and faculty welfare, and his rather direct challenge to Maxwell to bring "PBI's academic standards to a level comparable to her spiritual and moral standards," demanded sober reflection. ${ }^{58}$ The report was interpreted by Maxwell as an indication that it would be easier for PBI to retain its distinctive ethos and emphases without accreditation. This interpretation created the long-lasting impression that Witmer himself had discouraged PBI from seeking accreditation. Creating such a perception of support made Maxwell's resistance to accreditation unassailable both during, and well after, his tenure as principal. ${ }^{59}$

Personnel from PBI were regular participants at CCCE conferences. Despite the significant presence of AABC personnel and on-going interaction with other Bible school leaders with very different perspectives on the subject of accreditation, Ted S. Rendall, who twice served as the chairperson of the CCCE executive, continued to be a voice of caution. In a foreword to the

57 PBCA, Letter from L.E. Maxwell to Ray and Helen Shepherd, 13 July 1966. Jared Giesbrecht astutely notes that during the tumult between Columbia Bible College and AABC, Anthony T. Rossi, the multi-millionaire founder of Tropicana Orange Juice Company, withdrew his financial support from the college and channelled significant portions of it (almost a million dollars) towards PBI ("Education with Distinction," unpublished paper, 2002, 27-29). Thus by the mid-1960s there was a substantial financial incentive on the part of PBI for maintaining its aloofness from AABC in particular, and accreditation in general.

58 PBCA, Letter from R.A. Witmer to L.E. Maxwell and A.H. Muddle, 4 Mar.1960. 59 Interview with Charlotte Bates, Jan. 2002; and PBCA, "An Institutional Self Study of Prairie Bible College,” Draft, 4 Mar. 1992, 5-6. Witmer's report did, however, prompt the formation of an internal investigative committee "to improve the curriculum apart from any membership in or affiliation with an outside accrediting association" (Giesbrecht, "Education with Distinction," 18). In addition, the school's promotional materials began highlighting the total number of curricular hours devoted to the study of the Bible at PBI, which it claimed "exceeded" AABC requirements, cleverly implying superiority. 
1965 CCCE report, he acknowledged the "terrifying strength" of the "winds of change" and the need "to meet the demands of our time," but cautioned that "this must not be done by sacrificing those emphases which have made Bible school training distinctive...[namely] our Bible emphasis, our spiritual life teaching and our missionary vision." 60 PBI remained one of the most prominent voices within the Bible school movement, opposing all forms of accreditation until it faced a precipitous decline in student enrolments during the 1980s. Only then did the school's reluctance to grant degrees and seek accreditation diminish. In 1980, under the leadership of Rendall, the school was given a charter by the province of Alberta to grant degrees in "divinity," and in 1989 the school sought applicant status with AABC. ${ }^{61}$ The school did not, however, achieve full accreditation with AABC until 2001.

\section{An Assessment of AABC Influence on Bible College Accreditation}

The CCCE conference in 1965 marked a significant turning point in the internal role played by AABC. As in the past, AABC was given a prominent place on the program, but it proved to be the final time. Significant within this conference was the growing realization among Canadian Bible college leaders that, while AABC might be helpful for some schools in defining a standard of institutional excellence and in helping graduates enter schools in the United States, it was not likely to be the path for obtaining recognition from other post-secondary institutions in Canada. Mostert's presentation in 1965, "Problems and Responsibilities Facing Canadian Bible Institutes and Colleges in This Decade," highlighted in considerable detail the institutional responsibilities in the area of facilities, recruitment, admission, personnel, curriculum, and instruction, but offered only a vague reference to "difficulties of various sorts" when addressing "the problem of recognition" in Canada. ${ }^{62}$ It is difficult to understand why AABC personnel were not able (or willing) to help Canadian schools discover and pursue other avenues for obtaining recognition by universities in Canada when they were eager to serve as consultants

\footnotetext{
60 CCCE Report, 1965, 1.

61 PBCA, "An Institutional Self Study of Prairie Bible College," 1992, 4-5.

62 CCCE Report, 1965, 2-3.
} 
on virtually every other aspect of Bible college life. It is possible that they were entirely baffled by the absence of accrediting agencies governing the various facets of post-secondary education in Canada. It is more plausible to suggest that their "disinterest" grew out of a conflict of interest. Assisting Bible colleges in Canada in finding alternative avenues to academic recognition might well mean helping Bible colleges in Canada face the question of whether membership with $A A B C$ was in fact worthwhile. This was not an unfounded fear: several colleges, including Canadian Mennonite Bible College and Canadian Nazarene College, both located in Winnipeg, had negotiated arrangements during the late 1950s and early 1960s with local universities without ever pursuing $\mathrm{AABC}$ membership, and (as noted above) by 1971, MBBC had dropped its membership in AABC. ${ }^{63}$ Further, one wonders whether the level of collaboration and oversight demanded by universities in affiliate arrangements with Bible colleges exceeded the level of co-operation with which AABC personnel were comfortable. In the United States, AABC accreditation had played an important role in allowing Bible colleges to operate with complete autonomy. To have private, evangelical Protestant institutions create a liaison with secular universities was an almost unthinkable arrangement in the United States at the time.

In 1960, F.C. Peters was a lone voice in discussing Bible college-university relationships at the CCCE. Five years later, the number of Bible college presidents wrestling with the issue had increased. In a 1965 workshop entitled "Provincial University Recognition" that followed Mostert's address, five Canadian Bible college leaders, each working in a different province, offered detailed reports of their findings. The session concluded by identifying four forms of "recognition" by universities in Canada: affiliation, federation, individual recognition, and charters. Notable is the fact that $\mathrm{AABC}$ was not even mentioned as a vehicle for increasing recognition by Canadian universities, despite the fact that several of the presenters were administrators in schools pursuing AABC membership. ${ }^{64}$

63 See F. Stambrook, "A Sensible Solution: The Canadian Mennonite Bible College and the University of Manitoba," CMBC Alumni Bulletin (Spring 1990); Bruno Dyck, "Half a Century of Canadian Mennonite Bible College: A Brief Organizational History," Journal of Mennonite Studies 11 (1993): 194-223; and Dorothy J. Thomson, Vine of His Planting: History of Canadian Nazarene College (Edmonton: Commercial Printers, 1961), 32.

64 CCCE Report, 1965, 12-14. 
AABC's influence within CCCE was certainly successful in helping like-minded evangelical educators in Canada build fraternal relationships and co-operate in new ways. It was helpful in motivating faculty members to upgrade their academic credentials, and in guiding many Bible schools in improving the academic quality of their curriculum. In response to demands from students, many Bible school administrators found that holding up the target of accreditation helped motivate constituencies to find the financial resources necessary for upgrading facilities, library, and faculty. AABC accreditation helped make Canadian Bible colleges a more attractive consideration for American students; moreover, it offered students who had studied at Canadian schools, and who wished to continue their studies, a range of additional educational options in the United States.

As indicated in the table above, by 1966 five more schools in Canada had applied for membership with AABC, and still others were preparing their applications (eight Canadian schools applied during the 1970s). Despite AABC's obvious success in gaining academic recognition and transfer credit for Bible colleges in the United States, it was much less successful in helping Bible colleges in Canada become a recognized part of the larger post-secondary educational landscape. Although leaders in Canadian Bible schools initially looked to AABC personnel for guidance and expertise, it was ultimately left to Canadian leaders to discover for themselves precisely what $\mathrm{AABC}$ accreditation meant, and more to the point, what it did not mean, within the Canadian context during the 1960s. ${ }^{65}$

\section{A New Level of Canadian Initiative and Leadership}

65 During the 1990s, AABC accreditation gradually became more widely accepted as one (among several) considerations for Canadian universities in granting transfer credit requests from Bible college students. The long-standing admissions policies for admitting Bible college graduates used by Wilfrid Laurier University and Waterloo University established precedents, but as Peter Rae notes the impetus for policy change in many public universities often came from administrators and faculty in the two types of institutions who had come to know and trust one another (see Rae, "Unholy Alliance?" 270-71). Helpful in understanding the on-going struggle of Bible colleges in gaining academic recognition is a paper by Al Hiebert, who offers a variety of explanations for the resistance towards evangelical Bible colleges on the part of some Canadian universities: "Evaluating Credit Transfer Requests From Confessional Colleges and Seminaries," paper presented to the Association of the Registrars of Universities and Colleges of Canada, Edmonton, 25 June 2002. 
As the decade of the 1960s progressed, a larger range of issues related to the diverse aspects of college life including curriculum, organizational structure, pedagogy, student life, library, publicity, and admissions were featured on the CCCE program. More Canadians were invited to lead workshops, although the central speakers were almost always Americans. The most notable adjustment was the diminishing presence and role of AABC. In 1966, CCCE delegates decided to draft a constitution for creating a more formal organizational structure. ${ }^{66}$ Two years later, a constitution was presented to CCCE delegates for ratification, and with twenty-five charter schools endorsing the endeavour (all but two from western Canada), CCCE officially became the Association of Canadian Bible Colleges, signalling the beginning of a new era for the conference. Symbolic of the impulses that prompted adjustments within the new organization was the request by Arnold E. Airhart asking for a greater emphasis on "Canadian education" on the program, and for the selection of a speaker who is "a Canadian educator not connected to the Bible school movement." ${ }^{67}$ The conferences organized by the Association of Canadian Bible Colleges gradually became professional development events for all Bible school/college staff and not just meetings for top administrators or selected delegates. This emphasis, and the sidelining of the agenda on accreditation, helped broaden interest in the organization and increase attendance at annual conferences.

The 1960s represented a critical period of transition for evangelical theological education in Canada. Situated within a geographical region that was experiencing dramatic economic growth and an unprecedented demand for access to post-secondary education, many Bible schools began raising their academic standards, broadening their curriculum, and pursuing accreditation as a means to maintain their place within an educational landscape that was rapidly changing. The story of the CCCE serves as a unique window through which to observe an emerging evangelical Protestant network as individuals discovered each other and the benefits of working together, and wrestled with and responded to

66 CCCE Report, 1966, 75.

67 PBCA, Association of Canadian Bible College Executive Committee Minutes, 23 May 1968. Indicative of the growing interest in "Canadian" evangelical education was a presentation by Kenneth G. Hanna entitled, "The Need for Evangelical Scholarship in Canada," and the subsequent discussion about creating a "Western Canadian Sectional Chapter" of the Evangelical Theological Society (CCCE Report, 1968, 26-31). 
the broader trends and movements within Canadian society. This annual forum helped evangelical educators in Canada to position their schools as an educational option in ways that some of them had previously been unwilling (and perhaps unable) to do. The differences exemplified by schools such as MBBC and PBI reflect the variegated character of evangelicalism in the region. Many of the ethnic, immigrant denominational groups involved in the Bible school movement during the 1950s and 1960s were significantly more aggressive in responding to the growing enthusiasm for higher education in Canada than were the transdenominational institutions, which had stronger links to fundamentalism. The adjustments that began within the Bible school movement during the 1960s, and the influence of organizations like AABC, which encouraged Canadian educators to pursue graduate studies in the United States, laid the foundation for the next chapter in the story of evangelical theological education in Canada, when nearly a dozen evangelical Protestant graduate schools or seminaries were started in Canada. 